\title{
Nikolai N. Seleznyov
}

\section{(18.05.1971-13.05.2021)}

Yulia Furman | ORCID: 0000-0001-8649-2963

Seminar für Semitistik und Arabistik, Freie Universität Berlin,

Berlin, Germany

jufurman@zedat.fu-berlin.de

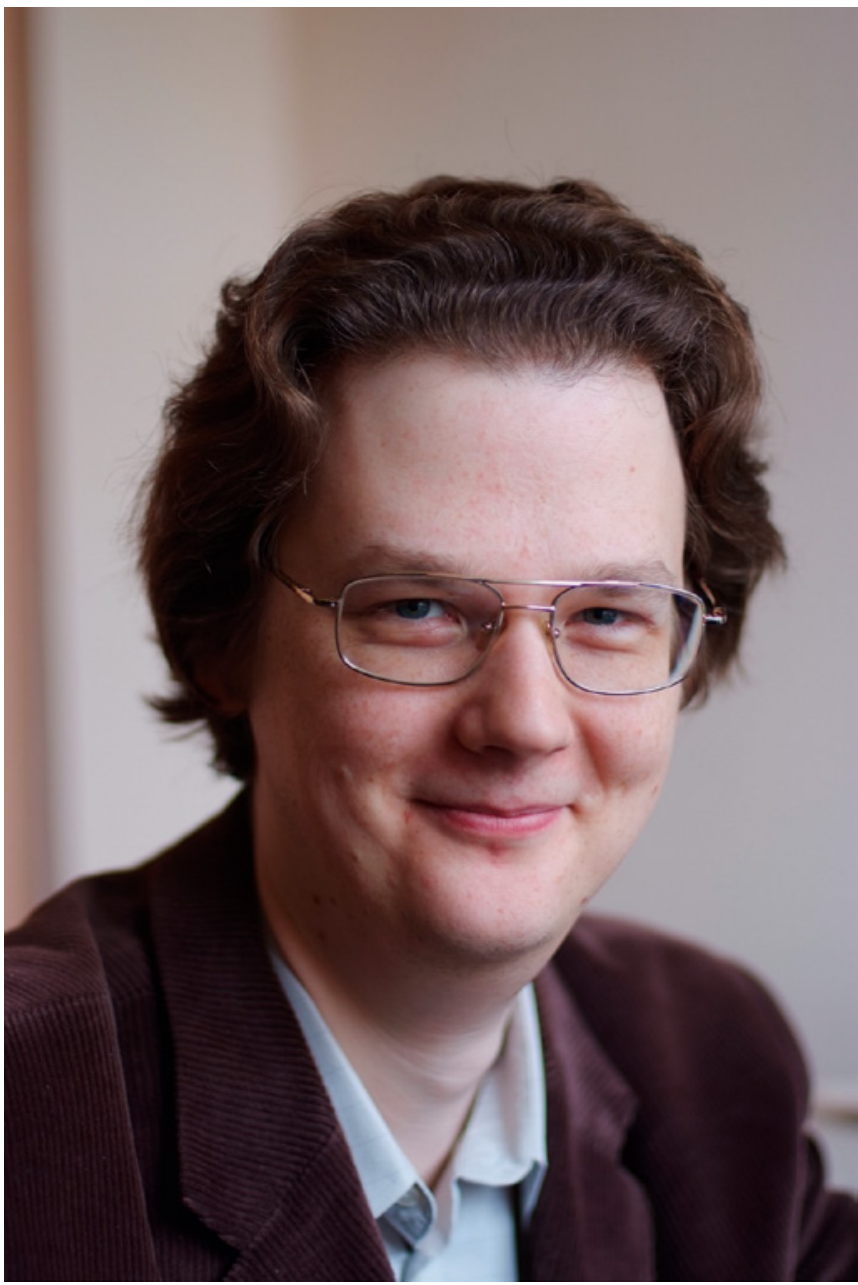

PHOTO BY EUGENY BARSKY

(C) YULIA FURMAN, 2021 DOI:10.1163/18177565-BJA10049

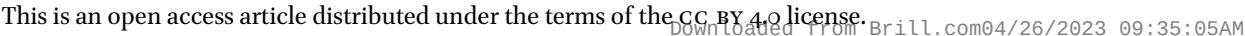


Nikolai N. Seleznyov, my teacher and Doktorvater, passed away on May 13, 2021, five days before his birthday when he would have turned 5 o. I became acquainted with Nikolai Seleznyov first as a lector when back in 2007 he taught us the history of Syriac literature during our second year at Russian State University for the Humanities. Nikolai's pedagogical talent was outstanding. He always inspired us with his sincere and fervent interest in this new and mysterious world and showed how one could navigate it. His intellectual and academic path was also marked with this inspiration as well as with the curiosity and enthusiasm of a pioneer. Once he explored a subject and made several discoveries, he would find a new one and fearlessly move to it. Thus, having spent a decade on studying the history of the Church of the East and the figure of Nestorius, he went on to the fascinating subject of intercommunal and interreligious relationships in the medieval Middle East. After Nikolai had finished and defended his habilitation on the Majälis of Elias of Nisibis in 2020, he came up with a surprising and unorthodox theme - Buddhism as reflected in medieval Arabic sources. It is beyond doubt that he would have found something groundbreaking and exciting again as soon as he shared the results of his inquiry into Buddhism. Nikolai Seleznyov may very well be characterized as a great expert in East Syriac and Arabic Christianity, but his scholarly career suggests that he was first and foremost an independent and original thinker and a researcher, who mined new knowledge.

Nikolai belonged to a type of scholar, who can grasp the essence of a subject without going into much details. I believe that this feature helped him reveal previously unnoticed links between seemingly unrelated phenomena.

Nikolai not only developed the field of Syriac Studies with his own work, but he also greatly assisted his colleagues from Russia and abroad in their research, be it a piece of good advice or help with finding necessary publications. He had a great electronic collection of scholarly literature, which made it possible for numerous papers and theses to be completed, especially 10-15 years ago, when Russian libraries were not sufficiently stocked, and subscriptions to various electronic resources were not so widespread.

In the past decade, Syriac and Christian Arabic studies have been flourishing in Russia. Many new names and works appeared in the Russian-speaking and writing milieu. Nikolai himself wrote predominantly in Russian and promoted the Russian school among the international scholarly community. Together with Grigory Kessel, he compiled a list of publications on the subject issued in Russian and published this annual report in the journal of Syriac Studies Hugoye.

Nikolai passed away so early und unexpectedly. It is a great loss for the entire field and even a greater loss for the Russian academic circles. Nikolai gave a 
powerful impulse to Syriac Studies in Russia, and it will surely continue beating in us, his colleagues, students, and friends ...

Dear teacher, you will be sorely missed.

Nikolai N. Seleznyov's complete bibliography

\section{Books}

1. N. Seleznyov, «Книга общности веры - средневековый восточнохристианский экуменический трактат [The Book of the Concordance of Faith - Medieval Oriental Christian Ecumenical Treatise], Moscow: Grifon, 2018.

2. N. Seleznyov, Книга собеседований Илии, митрополита Нисивина, с везиром Абу-л-Касимом ал-Хусайном ибн 'Али ал-Магриби и Послание митрополита Илии везиру Абу-л-Касиму [Book of Sessions by Mar Elias ('Iliyyā), Metropolitan of Nisibis, with Wazir Abū 'l-Qāsim al-Husayn ibn 'Alī al-Maghribī and the Epistle of Metropolitan Elias ('Iliyyā) to Wazir Abū 'l-Qāsim], Moscow: Grifon, 2018.

3. N. Seleznyov, Йоханнан бар Зо'би и его «Истолкование таин»: Критический текст, перевод, исследование [Yōḥannān Bar Zō'bī and his "Explanation of the Mysteries": Critical Text, Russian Translation from Syriac, and Investigation], Moscow: The Assyrian Church of the East, 2016.

4. N. Seleznyov, Pax Christiana et Pax Islamica: Из истории межконфессиональньх связей на средневековом Ближнем Востоке [Pax Christiana et Pax Islamica: On the History of Interconfessional Relations in the Medieval Near East] (Orientalia et Classica XLV), Moscow: Russian State University for the Humanities, 2014.

5. N. Seleznyov, tr. Богословские собеседования между Католикосом Церкви Востока Мар Тиматеосом I (727-823) и халифом ал-Махди, повелителем правоверных [The Dialogue between Catholicos Timothy and Caliph al-Mahdi, translation from Syriac into Russian], Moscow: The Assyrian Church of the East, 2005.

6. N. Seleznyov, Несторий и Церковь Востока [Nestorius and the Church of the East], Moscow: Put', 2005 .

7. N. Seleznyov, Христология Ассирийской Церкви Востока: Анализ основных материалов в контексте истории формирования вероучения [The Christology of the Assyrian Church of the East: The Main Documents and Development of the Doctrine], Moscow: Euroasiatica, 2002.

8. N. Seleznyov, Ассирийская Церковь Востока: Исторический очерк [The Assyrian Church of the East: A Historical Survey], Moscow: The Assyrian Church of the East, 2001. 


\section{Edited Volumes}

9. N. Seleznyov (ed.), Христианский Восток: государства и межконфессиональные связи [Christian Orient: The States and Interconfessional Relations]. Special issue of the journal State, Religion and Church in Russia and Worldwide, 33.2. Moscow: Academy of National Economy and Public Administration, 2015.

10. Y. Arzhanov, N. Seleznyov (eds.), Miscellanea Orientalia Christiana. Восточнохристианское разнообразие [Miscellanea Orientalia Christiana. Various Aspects of Eastern Christianity], Moscow: Probel-200o, 2014.

11. B. Lourié, N. Seleznyov (eds.), Syrians and the Others: Cultures of the Christian Orient in the Middle Ages. Scrinium:Journal of Patrology and Critical Hagiography, 10. Piscataway, NJ: Gorgias Press, 2014.

12. N. Mushelishvili, N. Seleznyov (eds.), Syriaca $\cdot$ Arabica $\cdot$ Iranica. Simvol: Journal of Christian Culture, 61. Moscow - Paris: St. Thomas Institute of Philosophy, Theology and History, 2012.

13. N. Mushelishvili, N. Seleznyov (eds.), Syriaca \& Arabica. Simvol: Journal of Christian Culture, 58. Moscow - Paris: St. Thomas Institute of Philosophy, Theology and History, 2010.

14. N. Mushelishvili, N. Seleznyov (eds.), Духовная культура сирийцев [Syriac Intellectual Culture]. Simvol: Journal of Christian Culture, 55. Moscow - Paris: St. Thomas Institute of Philosophy, Theology and History, 2009.

\section{Journal Articles}

15. G. Kessel, N. Seleznyov, "Bibliography of Syriac and Christian Arabic Studies in Russian, 2020," Hugoye:Journal of Syriac Studies, 24.1 (2021), pp. 299-316.

16. G. Kessel, N. Seleznyov, "Bibliography of Syriac and Christian Arabic Studies in Russian, 2019," Hugoye:Journal of Syriac Studies, 23.1 (2020), pp. 181-191.

17. N. Seleznyov, "Devatāsūtra в арабском «Сборнике летописей » Рашид ад-Дина" [Devatāsūtra in the Arabic Compendium of Chronicles of Rashīd al-Dīn], State, Religion and Church in Russia and Worldwide, 38.3 (2020), pp. 237-254.

18. N. Seleznyov, "Al-Makīn ibn al-'Amīd on Moses of Crete," Scrinium: Journal of Patrology and Critical Hagiography, 15.1 (2019), pp. 321-327.

19. G. Kessel, N. Seleznyov, "Bibliography of Syriac and Christian Arabic Studies in Russian, 2018," Hugoye:Journal of Syriac Studies, 22.1 (2019), pp. 295-305.

2o. G. Kessel, N. Seleznyov, "Bibliography of Syriac and Christian Arabic Studies in Russian, 2017," Hugoye:Journal of Syriac Studies, 21.1 (2018), pp. 127-141. 
21. N. Seleznyov, "Seven Sessions or Just a Letter? Observations on the Structure of the Disputations between Elias, Metropolitan of Nisibis, and the Vizier Abū l-Qāsim al-Maghribī," Scrinium: Journal of Patrology and Critical Hagiography, 14.1 (2018), pp. 434-445.

22. N. Seleznyov, “Антииудейская полемика в «Собеседованиях » Илии, митрополита Нисивина, и везира Абу-л-Касима ал-Магриби” [Anti-Jewish Polemics in the Disputations between Elias, Metropolitan of Nisibis, and Vizier Abū l-Qāsim al-Maghribī], State, Religion and Church in Russia and Worldwide, 36.2 (2018), pp. 300-314.

23. G. Kessel, N. Seleznyov, "Bibliography of Syriac and Christian Arabic Studies in Russian, 2016," Hugoye:Journal of Syriac Studies, 20.1 (2017), pp. 317-331.

24. N. Seleznyov, “« И вселиса въ ны »: Боговселение (al-ḥulūl) в мусульманскохристианском диалоге. Илия Нисивинский и Абӯ-л-Ка̄сим ал-Магрибй” [«И вселиса въ ны »: Incarnation (al-ḥulūl) in Muslim-Christian Dialogue. Elias, Metropolitan of Nisibis, and Vizier Abū l-Qāsim al-Maghribī], Christian Orient, 14.8 (2017), pp. 297-312.

25. N. Seleznyov, “Основы христианско-мусульманских отношений по свидетельству «Собеседований » Илии Нисивинского и везира Абу-л-Касима ал-Магриби" [Outlines of Christian-Muslim relations based on "The Book of Sessions" by Elias of Nisibis and Vizier Abū l-Qāsim al-Maghribī], The Historical Reporter, 20 (2017), pp. 294-307.

26. G. Kessel, N. Seleznyov, "Bibliography of Syriac and Christian Arabic Studies in Russian, 2015," Hugoye:Journal of Syriac Studies, 19.1 (2016), pp. 247-257.

27. N. Seleznyov, “Живой, Глаголящий и Незримый: Беседа Илии, митрополита Нисивина, и везира Абу-л-Касима ал-Магриби о единобожии и троичности" [Living, Speaking, and Invisible: The First Conversation between Elias, Metropolitan of Nisibis, and Wazir Abū l-Qāsim al-Maghribī], Volshebnaja Gora, 17 (2016), pp. 129-144.

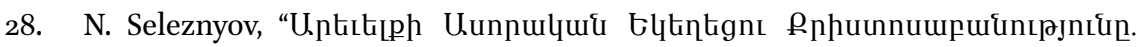

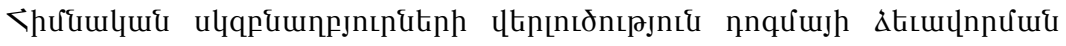

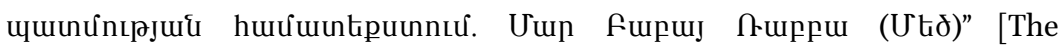
Christology of the Assyrian Church of the East (Mar Babai Raban the Great)], Etchmiadzin, 5 (2016), pp. 9-23.

29. G. Kessel, N. Seleznyov, "Bibliography of Syriac and Christian Arabic Studies in Russian, 2014," Hugoye:Journal of Syriac Studies, 18.1 (2015), pp. 125-145.

3о. N. Seleznyov, “« Ибо их Писание повелевает ... »: Четвертая беседа Илии, митрополита Нисивина, и везира Абу-л-Касима ал-Магриби” [“For their Scriptures Command...”: The Fourth Conversation between Elias, Metropolitan of Nisibis, and Wazir Abū l-Qāsim al-Maghribī], Vestnik of Saint 
Petersburg University. Series 9. Literary Studies. Oriental Studies. Journalism, 12.4 (2015), pp. 57-65.

31. N. Seleznyov, "Апологетический аспект средневекового несторианского энциклопедического сочинения «Башня » (Kitāb al-mağdal) на примере глав о любви (al-mahabba) и чистоте (aț-țahāra)" [Apologetic Aspect of the Medieval 'Nestorian' Encyclopedic Work “The Tower” (Kitāb al-mağdal): The Chapters on Love (al-mahabba) and Purity (aț-țahāra)], RSUH/RGGU Bulletin. Series: History. Philology. Cultural Studies. Oriental Studies, 3 (2015), pp. 9-20.

32. N. Seleznyov, “История экуменизма: Забытый ранний этап” [History of Ecumenism: The Forgotten Early Period], State, Religion and Church in Russia and Worldwide, 33.2 (2015), pp. 161-181.

33. N. Seleznyov, "Uptitiph Uunpulum bltintignt @phuunnumpuintpjnıin.

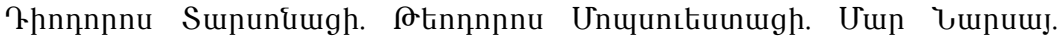
Utiunnn" [The Christology of the Assyrian Church of the East: Diodorus of Tarsus, Theodore of Mopsuestia, Narsai, Nestorius], Etchmiadzin, 12 (2015), pp. 24-54.

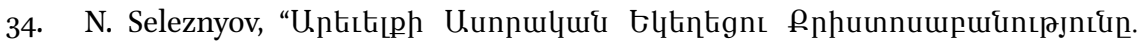

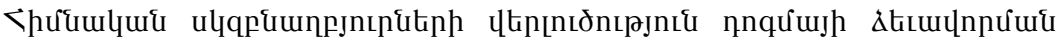

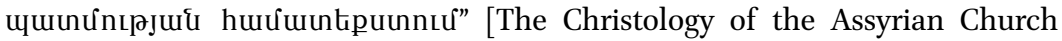
of the East: The Main Documents and the Development of the Doctrine], Etchmiadzin, 5 (2015), pp. 19-48.

35. G. Kessel, N. Seleznyov, "Bibliography of Syriac and Christian Arabic Studies in Russian, 2013," Hugoye:Journal of Syriac Studies, 17.1 (2014), pp. 132-140.

36. N. Seleznyov, "The Laments of the Philosophers over Alexander the Great according to The Blessed Compendium of al-Makin ibn al-Amīd," Scrinium:Journal of Patrology and Critical Hagiography, 10 (2014), pp. 97-114.

37. N. Seleznyov, “"These stones shall be for a memorial”: A discussion of the abolition of circumcision in the Kitāb al-Mağdal," Scrinium:Journal of Patrology and Critical Hagiography, 10 (2014), pp. 115-148.

38. G. Kessel, N. Seleznyov, "Bibliography of Syriac and Christian Arabic Studies in Russian, 2010-2012," Hugoye:Journal of Syriac Studies, 16.1 (2013), pp. 134-155.

39. N. Seleznyov, "Franks and Eastern Christian Communities: A Survey of their Beliefs and Customs by an Arabic-Speaking Coptic Author (MS Mingana Chr. Arab. 71)," Christian Orient, 12.6 (2013), pp. 150-161.

40. N. Seleznyov, "Jacobs and Jacobites: The Syrian origins of the name and its Egyptian Arabic interpretations," Scrinium: Journal of Patrology and Critical Hagiography, 9 (2013), pp. 382-398.

41. N. Seleznyov, "Изречения философов над гробом Александра Великого по «Истории » ал-Макина ибн ал-'Амида" [The Laments of the Philosophers over Alexander the Great according to The Blessed Compendium of al-Makin ibn al-Amīd], History of Philosophy, 18 (2013), pp. 248-267. 
42. N. Seleznyov, "Царствование императора Анастасия по «Благословенному собранию » ал-Макина ибн ал-Амида” [The Reign of Anastasius according to 'The Blessed Compendium' of al-Makin ibn al-'Amīd], Religiovedenie, 1 (2013), pp. 50-59.

43. N. Seleznyov, "Elias Geveri of Damascus" in Russian Studies of Church History: A Witness to the Two-Finger Sign of the Cross in a Medieval Treatise on Denominations of Syrian Christianity," Scrinium:Journal of Patrology and Critical Hagiography, 9 (2013), pp. 366-381.

44. N. Seleznyov, “Ибн Хазм о Боговоплощении и конфессиональном делении в христианстве" [Ibn Hazm on the Incarnation of God and Confessional Divisions in Christianity], History of Philosophy Yearbook, 2011 (2012), pp. 313-329.

45. N. Seleznyov, "Интерпретации происхождения названия «яковиты» у средневековых арабоязычных египетских авторов" [Interpretations of the Origins of the Name Jacobites by Medieval Egyptian Arabic Authors], RSUH/ RGGU Bulletin. Series: Oriental Studies. African Studies, 100.20 (2012), pp. 153-168.

46. N. Seleznyov, "Ираклий и Ишосйав II: Восточный эпизод в истории «экуменического » проекта византийского императора" [Heraclius and Ishō'yahb II: An Eastern Episode in the 'Ecumenical' Project of the Byzantine Emperor], Simvol:Journal of Christian Culture, 61 (2012), pp. 280-30о.

47. N. Seleznyov, “От франков до нубийцев: арабоязычный коптский книжник об особенностях христианских сообееств (по рукописи Mingana Chr. Arab. 71)" [From Franks to Nubians: An Arabic-Speaking Coptic Author on Beliefs of Christian Communities (MS Mingana Chr. Arab. 71)], Religiovedenie, 1 (2012), pp. 7-15.

48. N. Seleznyov, “Средневековый восточнохристианский экуменизм как следствие исламского универсализма" [Medieval Eastern Christian Ecumenism as a Result of Islamic Universalism], Philosophy Journal, 8.1 (2012), pp. 77-85.

49. N. Seleznyov, "Христианские сообщества на Востоке по свидетельству Леонхарта Раувольфа" [Eastern Christian Communities according to Leonhard Rauwolf], Tochki/Puncta, 11, 1-4 (2012), pp. 415-424.

5o. N. Seleznyov, “Хунайн ибн Исхак в « Своде основ религии » Ал-Му’тамана ибн ал-'Ассаля" [Ḥunayn ibn Isḥāq in al-Mu'taman ibn al-'Assāl's Records of Foundations of Religion], Volshebnaja Gora, 16 (2012), pp. 34-41.

51. N. Seleznyov, “«Коптский историк» - потомок выходца из Тикрита: Ал-Макин ибн ал-'Амид и его «История »" [“Coptic Historian” - a descendant of a native of Tikrit: Al-Makīn ibn al-'Amīd and his History], Tochki/ Puncta, 10.1-2 (2011), pp. 45-53. 
52. N. Seleznyov, “«Мелькиты » в арабо-мусульманском традиционном религиоведении" ["Melkites” in Traditional Arab-Muslim Religious Studies], Tochki/Puncta, 10.3-4 (2011), pp. 27-38.

53. N. Seleznyov, “Несторианский философ в коптской книжности: Ибн ат-Таййиб в пересказе Ибн ал-Ассаля" [A Nestorian Philosopher in the Arabic Literature of Copts: Ibn at-Tayyib retold by Ibn al-Assāl], History of Philosophy, 16 (2011), pp. 265-28o.

54. N. Seleznyov, “Сиро-палестинская мелькитская традиция: история обретения и утраты культурного своеобразия" [The Syro-Palestinian Melkite Tradition: From Getting to Losing its Cultural Identity], RSUH/RGGU Bulletin. Series: Oriental Studies. African Studies, 2 (2011), pp. 221-231.

55. N. Seleznyov, “Сочинение средневекового сирийского книжника в пересказе арабоязычного копта-энциклопедиста" [A Synopsis of the Treatise of a Medieval Syrian Author in an Arabic Summa by a Coptic Encyclopaedist], RSUH/RGGU Bulletin. Series: History/Studia classica et mediaevalia, 14 (76) (2011), pp. 266-279.

56. N. Seleznyov, "Annotated Bibliography of Syriac Studies in Russian 20o9," Hugoye: Journal of Syriac Studies, 13.1 (2010), pp. 108-117.

57. N. Seleznyov, "Nestorius of Constantinople: Condemnation, Suppression, Veneration; With Special Reference to the Role of His Name in East-Syriac Christianity," Journal of Eastern Christian Studies, 62.3-4 (2010), pp. 165-19o.

58. N. Seleznyov, “« Послание о единстве» багдадского мелькита в составе энциклопедического «Свода» арабоязычного копта XIII века" [“The Epistle of the Unity" by a Baghdadi Melkite in an Arabic "Summa" by a Coptic Encyclopaedist of the 13th century], State, Religion and Church in Russia and Worldwide, 3 (2010), pp. 151-156.

59. N. Seleznyov, "Восточносирийский автор рубежа XII - XIII вв. - Йоханнан Бар Зо'би - и его пролог к « Истолкованию таин »” [An East Syrian Author of the Turn of the 12-13th Centuries Yohannān bar Zocbī and his Prologue to "Explanation of the Mysteries"], Tochki/Puncta, 9.3-4(2010), pp. 9-48.

6o. N. Seleznyov, “Западносирийский книжник из Арфада и иерусалимский митрополит Церкви Востока. «Книга общности веры » и ее рукописная редакция на каршуни" [A West-Syrian Clerk from Arfād and the Metropolitan of Jerusalem, the Church of the East: "The Book of the Concordance in Faith" and its Recension in Karshūnī], Simvol:Journal of Christian Culture, $5^{8}$ (2010), pp. 34-87.

61. N. Seleznyov, "Христиане в сводном труде служащего мамлюкской канцелярии: ал-Калкашанди о христианстве и его основных конфессиях" [Christians in an Encyclopedic Work by a Mamluk Clerk: Al-Qalqashandī on 
Christianity and its Main Denominations], Simvol:Journal of Christian Culture, $5^{8}$ (2010), pp. 386-402.

62. N. Seleznyov, “Средневековое сочинение о конфессиях сирийского христианства и его использование в русской церковно-исторической науке" [A Medieval Treatise on Syrian Christian Denominations and Its Use in the Russian Church Historical Scholarship] // Vestnik Russkoi Hristianksoi Gumanitarnoi Akademii, 11.3 (2010), pp. 28-38.

63. N. Seleznyov, "Имя Нестория как символ и вопрос его почитания в восточносирийской традиции христианства" [The Name of Nestorius as a Symbol and His Veneration in the Tradition of East Syrian Christianity], Simvol: Journal of Christian Culture, 55 (2009), pp. 257-286.

64. N. Seleznyov, “Католикос-Патриарх Церкви Востока Мар Илия III и его «Слово на праздник Рождества Христова " [Sermon on the Nativity by Catholicos of the Church of the East Elias III], Simvol: Journal of Christian Culture, 55 (2009), pp. 389-395.

65. N. Seleznyov, "The Church of the East \& Its Theology: History of Studies," Orientalia Christiana Periodica, 74 (2008), pp. 115-131.

66. G. Kessel, N. Seleznyov, “Новые публикации по сирологии на русском языке” [Syrian Christianity: Recent Bibliography in Russian], Scrinium: Journal of Patrology and Critical Hagiography, 4 (2008), pp. 394-402.

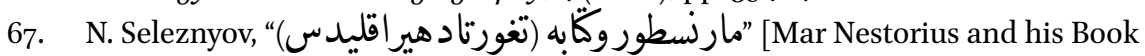
"The Bazaar of Heracleides"], 'Izgadda, 1.6-7 (2007), pp. 8-11.

68. N. Seleznyov, "Несторий и его апология « Книга Гераклида »" [Nestorius and his Book "The Bazaar of Heracleides"], Religiovedenie, 3 (20о6), pp. 16-27.

69. N. Seleznyov, "Несторий. Книга Гераклида Дамасского (избранное)” [Nestorius. Bazaar of Heracleides (selected fragments), translation from Syriac into Russian], Volshebnaja Gora, 12 (2006), pp. 66-82.

7o. N. Seleznyov, “Старообрядцы XVIII в. и «асирские христиане » Японии" [Russian Old Believers of the 18th Century and the "Assyrian Christians" of Japan], Volshebnaja Gora, 12 (2006), pp. 181-186.

71. G. Kessel, N. Seleznyov, “Новые публикации по сирологии на русском языке” [Syrian Christianity: Recent Bibliography in Russian], Scrinium: Journal of Patrology and Critical Hagiography, 2 (2006), pp. 481-487.

72. N. Seleznyov, "Уйгуры-христиане и их религиозно-историческая судьба" [Uighur Christians and their Religious Destiny], Volshebnaja Gora, 11 (2005), pp. 72-76. 


\section{Chapters in Edited Volumes}

73. N. Seleznyov, "Ya'qub och Jakobiter: Namnets syriska ursprung och dess Egyptiskarabiska tolkningar" [Jacobs and Jacobites: The Syrian origins of the name and its Egyptian Arabic interpretations], in: Jakobiter: Vilka är de? Uppkomsten av dagens syrisk-ortodoxa kyrka. En historisk bakgrund [Jacobites: Who are they? The origin of the modern Syrian Orthodox Church. A historical background], ed. Jan Bet-Şawoce. Södertälje: Nsibin, 2019, pp. 13-23.

74. N. Seleznyov, “Джавхар в мусульманско-христианском диалоге о Творце: Илия Нисивинский, Абу-л-Касим ал-Магриби, Ибн Хазм" [Ğawhar in Muslim-Christian Dialogue about the Creator: Elias of Nisibis, Abū l-Qāsim al-Maghribī, and Ibn Ḥazm], in «Рассыпанное » и «собранное »: когнитивные приемы арабо-мусульманской культуры ["Scattered" and "Brought Together": Cognitive Methods in Arab-Muslim Culture], ed. A.V. Smirnov. Moscow: Sadra, 2017, pp. 549-56o.

75. N. Seleznyov, “« Хотя и не обязательно для меня то, что приведено в Коране, я выведу из него доказательство »: Третья беседа Илии, митрополита Нисивина, и везира Абу-л-Касима ал-Магриби” ["Though it is not Obligatory for Me What is Stated in the Qurān, I will Get Proof from it”: The Third Conversation between Elias, Metropolitan of Nisibis, and Wazir Abū l-Qāsim al-Maghribī], in Ya evam veda... Кто так знает... Памяти Владимира Николаевича Романова [Ya evam veda...Кто так знает... In memoriam Vladimir Nikolayevich Romanov], eds. N.Y. Chalisova, N.V. Aleksandrova, M.A. Rusanov (Orientalia et Classica LXI). Moscow: Russian State University for the Humanities, 2016, pp. 349-363.

76. N. Seleznyov, “Адам и Слово: Второе собеседование Илии Нисивинского и Абу-л-Касима ал-Магриби" [Adam and the Word: The Second Conversation between Elias of Nisibis and Abū l-Qāsim al-Maghribī], in Источниковедение культурных традииий Востока: гебраистика - эллинистика - сирология славистика [Studies in the Cultural Traditions of the East: Hebrew - Greek Syriac - Slavonic], eds. C. von Büttner, N. Smelova. St. Petersburg: St. Petersburg Institute of Jewish Studies, 2016, pp. 261-276.

77. N. Seleznyov, “Коптская Церковь: Богословие” [Coptic Church: Theology], in Православная энииклопедия [The Orthodox Encyclopedia], Vol. 37. Moscow: Church Research Center “Orthodox Encyclopedia”, 2015, pp. 557-563.

78. N. Seleznyov, "“For they ascend to three madāhib as their roots": An Arabic Medieval Treatise on Denominations of Syrian Christianity,", in: «Рассыпанное » u « собранное »: стратегии организации смыслового пространства в арабомусульманской культуре ["Scattered" and "Brought Together": Strategies for Arranging Notions in Arab-Muslim Culture], ed. A.V. Smirnov. Moscow: Sadra, 2015, pp. 122-135. 
79. N. Seleznyov, “Семь канонов и девять знамений: Вероучительная часть литургической поэмы Йоханнана Бар Зо’би « Истолкование таин »” [Seven Canons and Nine Signs: The Doctrinal Part of Yoḥannān Bar Zołbī's Liturgical Poem "Explanation of the Mysteries"], in Miscellanea Orientalia Christiana, eds. N.N. Seleznyov, Y.N. Arzhanov. Moscow: Probel - 2000, 2014, pp. 92-127.

8o. N. Seleznyov, "Passio secundum Ibn al-Akfānī:учение христианских конфессий о крестных страданиях в традиционном арабо-мусульманском религиоведении" [Passio secundum Ibn al-Akfānī: The doctrine of Christ's Passions on the Cross in the Traditional Muslim Religious Studies], in Miscellanea Orientalia Christiana, eds. N.N. Seleznyov, Y.N. Arzhanov. Moscow: Probel - 200o, 2014, pp. 348-358.

81. N. Seleznyov, “Ал-Макин ибн ал-'Амид о Моисее Критском” [Al-Makīn ibn al-Amìd on Moses of Crete], in Иудаика и арамеистика. Сборник научных статей на основе материалов Третьей ежегодной конферениии по иудаике и востоковедению [Jewish and Aramaic Studies. The Proceedings of the Third Academic Conference on the Jewish and Eastern Studies, 17 December 2013], eds. K.A. Bitner, L.A. Lukincova. St. Petersburg: St. Petersburg Institute of Jewish Studies, 2014, pp. 151-161.

82. Y. Furman, N. Seleznyov, “От алфавита до причины всех причин: Йоханнан бар Зосби - восточносирийский автор монгольской эпохи и его трактаты в стихах" [From Alphabet to the Cause of All Causes: Yohannān Bar Zo'bī, an East Syrian Writer of the Mongol Period and his Tractates in Verses], in Institutionis Conditori: Илье Сергеевичу Смирнову [Institutionis Conditori: Ilie Sergeevichu Smirnovu], eds. N.P. Grincer, M.A. Rusanov, N.Y. Chalisova, L.E. Kogan, G.S. Starostin. Moscow: Russian State University for the Humanities, 2013, pp. 207-215.

83. N. Seleznyov, "Хроника или исторический роман? Царствование Зинона и события на Востоке по «Благословенному собранию » ал-Макина ибн ал-'Амида" [Chronicle or Historical Romance? The Reign of Zeno and the Events in the East According to The Blessed Compendium of al-Makīn ibn al-'Amīd], in Aeternitas. Сборник статей по греко-римскому и христианскому Египту [Aeternitas. A Collection of Essays on Greco-Roman and Christian Egypt], ed. A.A. Voitenko. Moscow: Centre for Egyptological Studies, Russian Academy of Science, 2012, pp. 120-148.

84. S. Brock, N. Seleznyov, "Ефрем Сирин: Богословие” [Еphrem the Syrian: Theological Views], in Православная энииклопедия [The Orthodox Encyclo pedia], Vol. 19. Moscow: Church Research Center "Orthodox Encyclopedia", 2009, pp. 100-104.

85. N. Seleznyov, "Foreword," in Indian Church History Lectures, ed. Most. Rev. Dr. Mar Aprem Metropolitan. Trichur: Mar Narsai Press, 2007, pp. 13-14. 
86. N. Seleznyov, “Древняя Церковь Востока” [Ancient Church of the East], in Православная энииклопедия [The Orthodox Encyclopedia], Vol. 16. Moscow: Church Research Center “Orthodox Encyclopedia”, 2007, pp. 265-266.

87. N. Seleznyov, “Дынха IV Мар, Хананья” [Dinkha IV Mar, Khanania], in Православная энииклопедия [The Orthodox Encyclopedia], Vol. 16. Moscow: Church Research Center “Orthodox Encyclopedia”, 2007, pp. 509-510.

88. N. Seleznyov, “Ассирийская Церковь Востока” [Assyrian Church of the East], in Большая Российская энииклопедия [Great Russian Encyclopedia], Vol. 2. Moscow: Great Russian Encyclopedia, 2005, pp. 375-376.

89. N. Seleznyov, V. Zadvornii, "Несторианство” [Nestorianism], in Католическая Энииклопедия [Katolicheskaya Enciklopedia], Vol. 2. Moscow: Izdatel'stvo Franciskancev, 2005, pp. 8о3-804.

9o. A. Marei, N. Seleznyov, "Китай" [China], in Католическая Энииклопедия [Katolicheskaya Enciklopedia], Vol. 2. Moscow: Izdatel'stvo Franciskancev, 2005, pp. 1035-1046.

91. N. Seleznyov, “Библия: Ассирийские переводы” [The Bible: Assyrian (NeoAramaic) Translations], in Православная энциклопедия [The Orthodox Encyclopedia],Vol.5. Moscow:Church Research Center “OrthodoxEncyclopedia”, 2002, pp. 187-188.

\section{Reviews}

92. N. Seleznyov, "Review of Noble, Samuel and Treiger, Alexander (2014) The Orthodox Church in the Arab World, 700-1700: An Anthology of Sources / Foreword by Metropolitan Ephrem (Kyriakos). DeKalb, IL.: Northern Illinois University Press. - 355 p.," State, Religion and Church in Russia and Worldwide, 33.2 (2015), pp. 304-308.

93. N. Seleznyov, "Review of Relations entre les peuples de l'Europe Orientale et les chrétiens arabes au XVII e siècle: Macaire III Ibn al-Za'īm et Paul d'Alep. Actes du Ier Colloque international, le 16 septembre 2011, Bucarest / Institut d'Études sud-est européennes de l'Académie Roumaine, Bucarest; textes réunis et présentés par Ioana Feodorov. Bucureşti: Editura Academiei Române, 2012," St. Tikhon's University Review. Series 1: Theology. Philosophy. Religious Studies, 46.2 (2013), pp. 124-127.

94. N. Seleznyov, "Review of H.Murre-van den Berg "Classical Syriac, Neo-Aramaic, and Arabic in the Church of the East and the Chaldean Church between 1500 and 180o" publ. in: H.Gzella, M.L.Folmer (eds.). Aramaic in Its Historical and Linguistic Setting. Wiesbaden: Harrassowitz, 2008, pp. 335-351," in Babel und 
Bibel 6: Annual of Ancient Near Eastern, Old Testament, and Semitic Studies, eds. L. Kogan, N. Koslova, S. Loesov, S. Tishchenko. Winona Lake: Eisenbrauns, 2011, pp. 562-563.

95. N. Seleznyov, "Review of Kessel, G., Pinggéra, K., A bibliography of Syriac ascetic and mystical literature. Leuven-Paris-Walpole, MA: Peeters, 2011. - (Eastern Christian studies, 11) - ISBN 978-90-429-2457-4-224 p.," // St. Tikhon's University Review. Series 1: Theology. Philosophy. Religious Studies, 42.4 (2012), pp. 123-124.

96. N. Seleznyov, "Рецензия на Джованни Гуайта, 1700 лет верности. История Армении и ее Церкви. (М.: FAM, 2OO2), 397 с., карт., илл., ISBN 5-89831-013-4” [Review of Giovanni Guaita, 1700 Years of Loyalty. The History of Armenia and the Armenian Church], Christian Orient, 10.4 (2002), p. 591.

\section{Translations}

97. J. den Heijer, “Отношения между коптами и сирийцами в свете открытий в Дейр ас-Сурйа̄н” [Relations between Coptsand Syrians in the Light of Discoveries at Dayr as-Suryān] (translated from English into Russian by N. Seleznyov), State, Religion and Church in Russia and Worldwide, 33.2 (2015), pp. 118-139.

98. A. Orlov, «Потаенные книги : иудейская мистика в славянских апокрифах ["Concealed Writings": Jewish Mysticism in Slavonic Pseudepigrapha] (translated from English into Russian by N. Seleznyov, A. Markov, I. Miroshnikov), Moscow: Mosti kulturi / Gesharim, 2011. 